\title{
African Universities as Employers of Returning Graduates from Germany: The Example of Ghana and Cameroon
}

\author{
Julia Boger
}

\section{The Potential of Universities for Development in Sub- Saharan Africa}

According to the Human Development Report of the United Nations Development Program (UNDP), economic underdevelopment continues to be a severe problem for most Sub-Saharan African countries (UNDP, 2015, p. 58). Policy makers have pinpointed universities in Sub-Saharan Africa as a potential tool for combating this underdevelopment. Universities with their three mandates of capacity building, research, and community have the potential to significantly stimulate development, especially in the periphery, by driving technological catchup (Bloom, Canning, \& Chan, 2006; World Bank, 2000, 2009, 2010). They seem to "play an important role as society's knowledge hubs, where concentrations of highly qualified senior faculty at the PhD level can engage in innovative research that contributes to national development" (World Bank, 2010, p. 26).

These high expectations have to be scrutinized (Schamp, 2014; see also chapter of Schamp in this volume) because most universities in Sub-Saharan Africa face great challenges, which makes it difficult to fulfill this potential. The higher education sector lacks financial resources, infrastructure, and-moreover-qualified personnel (Bloom, Canning, \& Chan, 2006, p. 6; World Bank, 2000, p. 23; World Bank, 2010, p. 22). Sub-Saharan African governments have made efforts to improve this situation and to increase the number of universities since the 1970s (Chien \& Kot, 2012, p. 1), but they are still unable to meet the growing demand for higher education. More capacity is needed to successfully educate the growing young population in Sub-Sahara Africa (UNDP, 2015, p. 157). An indicator of this need

\footnotetext{
J. Boger $(\square)$

World University Service, Deutsches Komitee e.V., Wiesbaden, Germany 
is the region's low gross enrollment ratio (GER) ${ }^{1}$. Even though there has been a rapid increase in enrollment in Sub-Saharan Africa, which stands at more than 5.2 million students, the GER for Sub-Saharan Africa is only 38\% (UNESCO Institute for Statistics [UIS], 2012, p. 128), which is the lowest worldwide. It is likely that a lack of universities is responsible for this low enrollment ratio. Despite a rapid growth of universities, their number is still too low to build academic capacities on a large scale. Teferra and Altbach (2004) refer to "no more than 300 institutions that fit the definition of a university" (p. 22) for the whole of the African continent. This number seems to have increased little since then. The homepage of the Association of African Universities (AAU) lists 359 member universities (AAU, 2015), not counting technical colleges and private universities. Another problem is the lack of academic personnel: The student-teacher ratios are very high. Lecturers have to deal with quite large class sizes and are thus only able to provide basic theoretical teaching. In consequence, the quality of tertiary education has deteriorated (World Bank, 2010, p. 23). Migration is the only way to meet the expectations that highly skilled graduates can improve development processes in Sub-Saharan African countries. However, educational migration cuts both ways. From the individual's perspective, educational migration is the best way to improve career opportunities, whereas from the labor market perspective it is seen as the cause of a brain drain of qualified personnel. This brain drain, as I point out in this chapter, creates a demand that could be filled by returnee graduates.

Educational migration has been common in most African countries since the 1960s. Large numbers of students have in the meantime gone abroad to pursue their higher education. Those were the early days after independence, when the higher education sector was in its beginnings in many countries, meaning that they lacked higher education institutions. Even though the situation of higher educational institutions has improved in many African countries, educational migration is still typical for Sub-Saharan African youth. Educational migration can even be regarded as a "cultural event," 2 as, for instance, Mbah describes it in her research on Nigerian university graduates (2017, p. 249).

In fact, statistics show that Sub-Saharan African students are the most mobile students worldwide (Chien \& Kot, 2012, p. 15). About 4.5 million students are internationally mobile. Of them, about 350,000 tertiary students from Sub-Saharan Africa are enrolled abroad and pursuing their tertiary education outside their own country (Organization for Economic Co-operation and Development [OECD], 2014, p. 361). Thus, $4.9 \%$ of Sub-Saharan African students are studying abroad, which is three times the global average of $1.9 \%$ (UIS, 2010, p. 4). About two-thirds of these

\footnotetext{
${ }^{1}$ The GER presents "the number of pupils or students enrolled in a given level of education, regardless of age, expressed as a percentage of the population in the theoretical age group for the same level of education. For the tertiary level, the population used is the 5-year age group starting from the official secondary school graduation age" (UIS, 2012, p. 66).

${ }^{2}$ For more on an African perspective on "cultures of migration" see Hahn and Klute (2007).
} 
mobile students enroll in tertiary institutions in the Global North, preferably in North America and Western Europe.

Germany plays an important role as a host country for these students from the Global South, a situation that also has to do with increasing competition for the best talent among European universities (Kuptsch, 2006). These students are subject to diverging policy approaches. On the one hand, actions are taken to retain the best of these international students in the face of an expected demographic change that will supposedly result in a shortage of young, skilled labor. On the other hand, since the 1970s, the German government has been acting to facilitate the return migration of these graduates through, for instance, organizations such as the Centre for International Migration and Development $(\mathrm{CIM})^{3}$ or by offering specific reintegration preparation seminars by the German Academic Exchange Service. The German government supports such reintegration schemes because highly skilled migrants are perceived to be "change agents" (Faist, 2008) who have the potential to stimulate development processes through knowledge transfers upon their return (Skeldon, 2005). However, to become such a change agent, returning graduates need career opportunities allowing them to apply their acquired knowledge. Recent studies (Morris-Lange \& Brands, 2015, p. 20) indicate that $44 \%$ of international university students who successfully graduate in Germany remain there, while the other $66 \%$ migrate to a third country or return home. ${ }^{4}$ Is this also the case for Sub-Saharan African graduates from German universities?

However, the proportion of potential change agents from Sub-Saharan African countries is quite moderate in Germany. About 10,000 students from Sub-Saharan Africa are currently registered in Germany, a figure that has not changed much since the start of the millennium. This amounts to around $10 \%$ of all students from countries in the Global South studying in Germany (German Federal Statistical Office, 2015a). ${ }^{5}$ Even though these figures are not high, this comparably small group of migrants could have a great impact on development. Many empirical studies suggest that Sub-Saharan African educational migrants wish to contribute to their home countries' development and that they enter the higher education sector upon returning there. This assumption has been strongly supported by Mbah's research on educational migrants from Nigeria (2014) as well as by a multicountry

\footnotetext{
${ }^{3}$ These reintegration subsidy schemes include transport and travel tickets, salary subsidies, and workplace equipment. Institutions that administer these subsidies are, for instance, the Migration for Development Program run by CIM and funded by the Federal Ministry for Economic Cooperation and Development (BMZ). The CIM partnered in the returning expert subsidy scheme with the German committee of World University Service (WUS), a non-government organization (NGO) that earlier designed the reintegration subsidy scheme of the 1980s. Another program, similar in its function but much smaller in terms of participants, is run by the German Protestant Relief organization Brot für die Welt (Bread for the world). (Further information about the German government's reintegration subsidies can be found in Schmidt-Fink, 2009).

${ }^{4}$ The study also offers an overview on the different estimations about return and retention rate of foreign students which the latter differs between 22\%-56\% (Morris-Lange \& Brands, 2015, p. 20). ${ }^{5}$ Currently, the majority of foreign students are from China and Russia, followed by India and Cameroon (German Federal Statistical Office, 2015b).
} 
investigation carried out by SOFRECO (2015, p. 72). This SOFRECO study examined the contribution made by students from thirteen different Sub-Saharan African countries who had studied abroad to capacity building in the field of higher education in Africa. But in my opinion, these studies limit their focus to the individuals' motivations, while ignoring the key issue of how they find jobs. This information gap concerning the job-finding phase is quite surprising, because it would be very interesting for policy makers in higher education as well as in migration management to know if and how these students from Sub-Saharan Africa are actually able to apply professionally what they learned in Germany.

I therefore offer insight in this chapter into the job-search process of Ghanaian and Cameroonian graduates returning from Germany. I compare these two Sub-Saharan African countries because both suffer from similarly high numbers of outgoing educational migrants. This exodus, as I argued previously, causes a shortage of qualified personnel in the economy-and in the countries' universities. One could, therefore, assume that returning academics have excellent job opportunities in this section of the labor market. But the experiences of returning graduates in both countries reveal that despite this foreseeable demand for their expertise, they still find it quite difficult to obtain employment in the higher education and, moreover, to sustain it. I show as well that even though the challenges of reintegration are high, an impact on development can be surmised at an institutional level, at least for the country case of Ghana.

In this chapter I present the theoretical background of the migration and development nexus, and sketch the theoretical outlines on return migration. I then use statistical material to describe the educational migration from Ghana and Cameroon to Germany and the return rate of graduates. My empirical material consists of 14 selected interviews from my $\mathrm{PhD}$ survey's sample $(n=50)$ conducted during fieldwork in Ghana and Cameroon (2008-2010). These interviewed returning graduates had started their professional careers in the higher educational sector. Eight of them had returned to Ghana and six of them to Cameroon. The interviewees were selected from the STEM disciplines (science, technology, engineering, and mathematics) because of these subjects' popularity among foreign students in Germany.

I conclude by asserting that graduates who start as lecturers in Cameroon seem to have mastered higher hurdles than their Ghanaian counterparts. Thus, it appears that Ghanaian universities have been more welcoming of their returning graduates than those in Cameroon. Hence, the problems upon return are similar in both countries but the weighting of the challenges varies according to the country context. This particular finding is discussed against the background of the debate surrounding the migration and development nexus. 


\section{The Migration and Development Nexus}

The interconnectedness of migration and development processes can be explained in two ways. Firstly, migration can be regarded as a response to development and underdevelopment. From this perspective, lacking economic development pushes people from the poorer countries in the Global South to the more developed countries in the Global North. Better income and living prospects attract people and motivate them to leave their homes. Secondly, migration itself can create underdevelopment and development. The latter perspective has become a comprehensive interdisciplinary debate labeled as the migration and development nexus (Nyberg-Sørensen, Van Hear, \& Engberg-Pedersen, 2002).

Economists investigate the extent to which the financial transfers of migrants, the remittances, influence development processes; sociologists and social anthropologists explore the impact of those living abroad (today often are referred to as diaspora communities) ${ }^{6}$ on cooperation projects, and last but not least, geographers scrutinize to what degree migration causes a brain drain, brain gain or a brain waste. The migration and development nexus debate started in the 1960s and studies particularly on return migration were conducted by different disciplines, often yielding very divergent results. In some cases, return migration was seen as a success, in others as a total failure. In fact, the findings seemed to swing back and forth between optimism and pessimism like a pendulum (de Haas, 2008). ${ }^{7}$ However, today's paradigm of transnationalism understands return migration as a part of the whole migration story - which allows investigating this form of migration without judging it.

What impact migration has on development depends on the notion of development being applied. Against the backdrop of an economically oriented development terminology, a negative impact was diagnosed in discussions about the negative effects of the brain drain in regard to the 1960s south-north migration processes. By then, most countries in the Global South, including the Sub-Saharan African countries, had declared their independence from the colonial powers in Europe. In consequence, many young citizens were encouraged to leave their native countries for the Global North to increase their knowledge and to return with this additional know-how. These highly skilled returning migrants were supposed to build the administrations of these young nations that were in need of highly qualified

\footnotetext{
${ }^{6}$ Today's discourse in migration studies relates diaspora to many groups of persons, mostly ethnic or religious minority groups living outside their countries of origin (e.g., on the African Diaspora, see Zips, 2003). Despite its widespread use, the term diaspora has become increasingly controversial, especially among authors of Jewish Studies who point out the religious and symbolic aspects of the term. Originally, the term diaspora (Greek, for scatteredness) was related to the situation of the Jews outside their Promised Land. Instead of a general definition, Krings proposes a more sensitive and refined treatment of the concept of diaspora as an analytical concept for the designation of a "specific transnational community form" (Krings, 2003, p. 151).

${ }^{7}$ For more details on how the migration and development debate shifted from a positive to a negative frame, and back again, see de Haas (2012).
} 
specialists. But very soon the students did not return after graduation. They started to settle in their host countries. There they found a better lifestyle, better income prospects, and political stability, as well as better working and research conditions. Brain drain, the permanent loss of highly skilled persons, had started. This brain drain intensified with the economic decline of many African countries in the 1970s. Moreover, austerity measures in the countries' public sectors due to structural adjustment programs made most countries' economies rather unattractive for welleducated graduates who had been exposed to a more developed economic environment, with the result that even fewer academics returned from abroad. This permanent outmigration from the Global South to the richer North is still ongoing and continues to cause great problems for the labor markets in the Global South. It has severe negative effects on sensitive sectors in the source countries, such as the health and education sectors, because of a shortage of physicians, health staff, and university lecturers (Manuh, Asante, \& Djangmah, 2005; Nyonator \& Dovlo, 2005).

Return migration of highly skilled migrants has been strongly regarded as an effective countermeasure against brain drain since the 1960s. Thus, many policy makers vigorously promoted return migration and even launched reintegration programs. They assumed that migrants could contribute to the development processes in their native countries by transferring their gained knowledge, while also disseminating democratic ideas. In this positive notion of return migration, it was assumed that returnees would generally be able to stimulate development processes upon their return. However, this was and is not always the case, with the actual impact of returning migrants depending on the individuals' situation and their motivation for the return. Cerase (1974) developed of a typology of returning migrants' motivation. He distinguished between a return of failure, in cases when migrants do not achieve their goals abroad; a return of conservatism, when migrants consider their savings to be economically better invested in their home countries; a return of retirement; and finally a return of innovation, which might be the most promising type in connection with development processes. The effectiveness of a return of innovation has been questioned, for not all returnees will turn out to be successful innovators. The outcome depends on the country context and the individuals' resources.

Studies suggest that return migration to Asian countries can be quite successful. This is especially the case for China, India, and, in general, countries with emerging markets. Their economies depend on innovation and they therefore urgently need highly skilled employees (Saxenian, 2005). High demand can lead countries such as China to actively encourage their academics to return from overseas. The Chinese government even sends out delegations to recruit Chinese students while they are still studying abroad (Zweig, 2006, p. 195). Sub-Saharan African countries are generally less economically developed and politically stable. Moreover, many African governments have recruited foreign-born development staff. These three factors greatly reduce employment opportunities for those highly skilled graduates who return (Thomas, 2008). And employment opportunities are one of the three greatest motivations for graduates to return from abroad, as a recent study (SOFRECO, 2015, p. 64) shows. 
Apart from this country context, the chances of success depend to a great degree on the individual returning migrant's resources and degree of preparedness (Cassarino, 2004). This preparedness includes-besides the willingness to return - tangible resources (financial reserves, educational certificates) and intangible ones (social contacts, knowledge of the country's labor market) that have to fit into the country context. However, these former approaches and theoretical concepts are all based on the assumption that migrants either return or remain abroad, whereas today's transnational paradigm assumes that migrants increasingly have circular mobility patterns. Vertovec (2007, p. 5) even suggests that such transnational migrants are likely to continue to migrate because each of their migrations and experiences abroad provides them with more knowledge about the country context, making them better able to choose their place of working and living. Unhindered transnational migration seems to describe only a minority (Portes, 2003). The majority of migrants still settle rather permanently either in the host or the source country. One major factor among others that can influence whether a person settles permanently or leaves again after returning to their home country is socioeconomic welfare. Returnees need to find a secure income generating activity (Thomas, 2008, p. 654), but finding a job is not easy, particularly if the jobs are in an environment with intransparent labor markets and comparably small formal job market sectors, as is often the case in the Global South. Thus, the SOFRECO study identifies possible difficulties finding a job as one of the greatest fears of Sub-Saharan African students abroad. In their view governments are negatively involved in employment decisions regarding academics, with recruitment not being based solely on merit, but on ethnic affiliation and social background. This entanglement was claimed by the respondents of the study in Cameroon, Ethiopia, and Sudan: "decisions for appointment are not taken on the basis of skills, talents and possible contributions but on political views and affinity" (SOFRECO, 2015, p. 78; see also Mbah, 2017 and chapter of Schamp in this volume). In the following I address the question of whether this rather opaque job placement practice also affects Ghanaian and Cameroonian graduates returning from Germany to work in their countries' higher education sectors.

\section{Returning to Ghana and Cameroon as Academics}

Ghana and Cameroon are Sub-Saharan African countries that are severely affected by a vast outmigration of their citizens to the Global North. An estimated 1.5 to 3 million Ghanaians (Quartey, 2009, p. 13) and 2.5 to 4 million Cameroonians (Owono, 2011; Sapouma, 2011) are living abroad. Compared to this total stock of emigration, educational migration flows are small in volume. In 2010, 20,093 Cameroonians went abroad to study (UIS, 2012, p. 136), which according to the Migration Fact Book (World Bank, 2011, p. 85) amounted to only $7 \%$ of the total emigrationstock of 279,200 in that same year. For Ghanaians, the proportion was even smaller: Of the total emigration stock of 824,900 (World Bank, 2011, p. 124), only 7,845 (1\%) were students (UIS, 2012, p. 137). This percentage distribution is 
reflected in the figures for Germany, where Cameroonian students far outnumber Ghanaian students. In 2015, about 579 Ghanaians pursued their tertiary education in Germany (German Federal Statistical Office, 2015a). This is only about 2\% of the total number of 29,590 Ghanaians registered in Germany (Ausländerzentralregister, 2016, p. 39). In contrast, the number of Cameroonian students is currently 6,672 (German Federal Statistical Office, 2015a), which amounts to almost 34\% (Ausländerzentralregister, 2016, p. 39) of the total number of 19,800 Cameroonians living in Germany in 2015. Statistics show that the majority of students from both countries are enrolled in technical subjects. Cameroonian students tend to prefer electrical engineering, while Ghanaian students seem to have a strong preference for master's programs in natural resource management (Boger, 2013, pp. 97-99).

Of these highly skilled migrants, only a small proportion return to their home countries. Estimates based on the internal statistical data of the reintegration subsidy programs administered by CIM suggest that 323 Ghanaian graduates returned from Germany during the decade 2000-2010, whereas only 288 Cameroonian graduates returned during the same period (Boger, 2014, pp. 137-139).

Despite its comparably small volume, the return of these educational migrants is my main interest. The question is not only whether they return, but also whether those who do return will be able to find adequate employment that also has a positive impact on the situation of their countries work in order to change their home countries for the better. How do they find their jobs and could they be better informed about the transition they face upon return?

The tertiary sector with its services is the main employer of university graduates in many Sub-Saharan African countries. A large proportion of these graduates find work in the field of education (Asong \& Awama, 2014, pp. 159, 164; Mugabushaka, Teichler, \& Schomburg, 2003). The institution of the university enjoys a very popular image as an employing structure within this field for several reasons. Being a professor at a university is a comparably secure job that also offers financial and social advancement, with a lecturer position in many countries supplemented by nonmonetary benefits, such as a car, housing, and health insurance. Moreover, working as a professor at a university creates a rising social status. Higher social status may open doors to a career in politics or as a consultant for international donor organizations (Neubert, 2008, p. 100). Coming back to this paper's empirical cases of returning Ghanaian and Cameroonian graduates, the situation in their native countries is similar: There is a great demand for highly qualified lecturers in both countries. In Ghana, there are currently 10 public universities, 10 technical colleges, and 63 private universities (Ghanaweb, 2015; National Accreditation Board, 2015). According to the Cameroon Ministry of Higher Education (2014) that country currently has 8 public universities, ${ }^{8} 6$ vocational training centers (p. 31), and 163 private institutions (p. 40).

\footnotetext{
${ }^{8}$ The eighth university, the University of Bamenda in the Anglophone region of the country, opened in 2011, after the data collection took place.
} 
As was mentioned previously, the demand for qualified university staff is high because enrollment in the tertiary sector is increasing in many Sub-Saharan African countries, which means that university capacities also have to rise. Moreover, the demand for lecturers with practical expertise is growing because of expanding implementation of what is known as the third mission of tertiary institutions, as Zajontz (2010) described for the case of Cameroon.

This third mission goes beyond teaching and research (second mission) to include practical entrepreneurial skills. These additional and less theoretical skills should prepare the graduates for starting their own spinoffs in a labor market in which formal employment is scarce. To fulfill this task, universities need highly qualified staff members with knowledge about modern techniques and practices. Returning graduates who have been exposed to more proactive educational environments and modern curricula abroad could offer such practical skills and would therefore seem the ideal choice for such academic positions. It has been observed that returning graduates have indeed found employment at their home countries' higher education institutions, such as universities, as well as at research centers and think tanks attached to universities (SOFRECO, 2015, p. 7; for the case of Ghana see Martin, 2005, p. 206; for the case of Cameroon see, Schamp \& Zajontz, 2008, p. 65).

This positive description of the university as a potential employer ignores the fact that workplaces at most Sub-Saharan African universities are not well equipped, which is regarded by African scholars abroad as a major constraint to their becoming more involved in African higher education (SOFRECO, 2015, p. 7). These deficits cause teaching quality to deteriorate further. Martin (2005, p. 209) and Manuh, Asante and Djangmah (2005) described this for the case of Ghana:

For many academics, frustration in many cases is not due only to low salaries, but also to the
conditions under which teaching and learning occurs; the shortage of space for lecturers and
tutorials; the lack of adequate materials including books and chemicals; increasing
enrolments leading to inadequate counselling for guidance for each student; production of
low grade/half-baked intellectuals. Job dissatisfaction, disillusionment and similar factors
lead to withdrawal and stress of faculty, and contribute to the push factors for brain drain.
(p. 265)

This detailed status description applies not only for Ghanaian universities, but to similar situations at most Sub-Saharan African universities, including those in Cameroon. Similarly, Zajontz (2010, p. 267) noted that respondents criticized university recruitment practices in Cameroon, claiming that universities would only "officially" follow clear hiring guidelines, such as age, number of publications, and educational experience, but in reality their recruitment procedures were rather opaque and incomprehensible to outsiders.

Summing up, although the tertiary sector in Ghana and Cameroon seems to offer a career opportunity for those graduates who return, entering the academic sector and working under the conditions there seems problematic. The people interviewed for this study spoke about the issues involved with seeking employment and working in the educational field. 


\section{Entering the Academic Labor Market in Ghana and Cameroon}

Graduates who study abroad and return to their native country undergo a double transition (see also Mbah, 2017). They not only have to reintegrate into their native countries' social environment, find a place to live, and readjust to the native's way of living, they must also enter their home countries' labor markets. This can, of course, be somewhat difficult because they usually left their home countries with little or no knowledge about the labor market there, and any knowledge they originally had has become outdated during the several years they were abroad studying. The job search is difficult for graduates in Sub-Saharan African countries in general, as Mugabushaka, Teichler and Schomburg (2003) pointed out in their comparative case study on Ghana, Nigeria, Kenya, Tanzania, Uganda, and Malawi:

Most African countries have public job centers, which allocate jobs to graduates, but in times of anticipated difficult transition, graduates cannot rely on those agencies alone. They are often forced to find more resources and pro-active solutions to the problem of finding employment. (p. 65)

This finding also applies to my case study on Ghana and Cameroon. The interviewees' narratives show that although they job-searched proactively they still faced difficulties identifying a vacant position, overcoming bureaucratic hurdles, and eventually remaining employed and improving their employment status. Apart from these generally similar findings, there was a significant difference. Ghanaian graduates seemed to fear the process of establishing a career in the university sector less than the Cameroonian graduates, who described their entry into the academic sector as comparably more dependent on personal contacts, which for some was a cause of great uncertainty. It also appeared that universities offered less career opportunities than their Ghanaian counterparts.

\section{Identifying a Vacant Position at the Universities}

In general, finding a job greatly depends on the flow of information about open vacancies. Today, information about jobs is often channeled through what is known as the hidden jobs market. Positions are not openly published, but announced via personal contacts and social networks. But how can returning graduates activate their social networks in the home country while they are still abroad?

In both countries, most interviewed returning graduates revealed that they had first started to search for a job upon returning. They reported that it was initially difficult for them to find an open position at a university. Many interviewees described the process of finding a job as based on luck and said that they had coincidentally met the right person, who had given them valid background information about potentially vacant positions. 
Dr. E. ${ }^{9}$, a Ghanaian graduate who had studied a quite specific subject, aquatic science, at the University of Bremen, knew that "to get a permanent job like this [at the university], it takes time" (Ghana interview \#22, 2009). Looking back at the time of his job search in 2001, he recalled that it was a personal contact, a former professor, who told him about a vacancy in a new department that would be opening soon:

So when I came back and I was looking for job, one day I came to the university. I think I came to look for school in Cape Coast. I came to the university and I saw one of my old professors. When I told him he said, oh, they have started new department fisheries and aquatic science .... That I can apply to it. When I applied, I think it took about six months. Then, they wrote to me that I should come for interview. So they called me for interview .... Then all the questions, I tried my best to address them. So after two weeks or so, they wrote to me that I have been appointed as assistant lecturer on one year probation. (Ghana interview \#22, 2009)

What Dr. E. clearly outlines in his statement is that it was a coincidence that he was able to find a vacancy. He had been looking actively for a position for a while and it was only when he met a former professor by chance that he learned about a position opening. He even frankly declared that without this particular information from his professor, he would not have gotten the job: "So, I think Prof., he did well because if he hadn't told me, I wouldn't have even applied" (Ghana interview \#22, 2009).

It seems crucial to have good contacts who can provide information, as the following case of Mrs. L. ${ }^{10}$ from Ghana (case \#20) also shows. Upon returning, a friend advised her where to search for a job:

I think, I knew a friend who was an assistant lecturer here. So, I think I gave him a phone call and he told me that I just have to go to the head of department. Find out from the head of department if they need somebody. If they need somebody, they will let me apply. So he said if the head of department assures me that there is a vacancy and that they need my services, then it won't be a problem. So I think I asked and I was shown to the agricultural engineering department. When I went there, I met the immediate past head of department. I told him my intentions, he said ok. He said ok because they need people. They need people ... even still one person teaches about four to five courses. So if I come, it will be of help. (Ghana interview \#20, 2009)

Interestingly, Mrs. L. had been advised by her friend to inquire about valid information directly by the head of department. This, from a northern European standpoint, could seem quite surprising. In the Global North it is general policy to

\footnotetext{
${ }^{9}$ Dr. E. studied aquatic sciences in Germany and returned to Ghana on September 1, 2001. Upon return he had difficulty finding a job. Eventually, after a cumbersome job search, he secured a position as an assistant lecturer at the University of Cape Coast in the department of Fisheries. Because he could not advance in his career, he decided to continue his education and to earn a doctorate in Germany. The second time he returned was in May 2008. The interview took place one year later on September 4, 2009, in his office in Cape Coast.

${ }^{10}$ Together with her husband, Mrs. L. studied resources engineering in Germany and they both returned to Ghana on December 1, 2006 with a master's degree. She secured a job as a lecturer five months later at the University of Ghana. The interview took place in her office almost three years later, on September 1, 2009.
} 
advertise a vacancy more transparently in media such as newspapers, radio, job placement centers, or the Internet. The friend's advice shows that this is not the case in Ghana and that personal contacts serve as better information channels.

As in the previous cases from Ghana, Dr. L. from Cameroon (case \#05) ${ }^{11}$ described that he secured information about a prospect vacancy from a personal contact. He coincidentally met a Cameroonian scientist during his years at the Technical University in Berlin. The scientist was a guest lecturer from a newly opened university in Cameroon and thus had access to information that the university needed qualified lecturers:

So I met him [the Cameroonian guest lecturer] and we discussed and he told me because I was really interested in knowing how the market job is in the country and he told me. He said that university lecturers, they have a chance to be recruited and particularly in the University of Buea ... it was a new university and ... he told me that they were looking for lecturers particularly in my field .... So he told me that I had good chances. So I said ok, I will not miss that opportunity. So he came here and he met the head of department. So the head of department welcomed me in 2002. I came here for a visit in 2002 to get in touch with them. I discussed with the head of department and he was very happy to hear that I want to come and join them here. (Cameroon interview \#05, 2008)

The demand for qualified lecturers at Buea, which by then was a new university was great, as shows the following case of Dr. G. ${ }^{12}$ from Cameroon (case \#04). In contrast to the previous example, she had no personal contact who gave her information prior to her application phase. She investigated the situation in Cameroon during a visit before she graduated in Germany. During this visit, she applied at various universities:

I have been sending my applications to four universities here but it is only in University of Buea where they said "ok here is a free place". In other universities there was no open position .... . They [the universities] normally don't reply. They reply if they want you to come .... If you don't get any reply it means there is no position ... yes the university of Buea replied and we settled everything before I come back everything was already done, yeah [laughs]. (Cameroon interview \#04, 2008)

In contrast to the previous narrative, she did not mention any personal contact. Thus, I became curious during the interview and inquired whether she had known someone in Buea. She negated this:

No, not really, to tell you the truth, when I came in February 2005, I was still working in Germany and I asked for permission, one week permission, to come for the interview. It was my first time in Buea ... and I met the head of department the one I was talking of, Dr. A., yes, and he was very nice. He welcomed me and said "Ok, since you are already in

\footnotetext{
${ }^{11}$ Initially, Dr. L. studied geology in Russia and returned for the first time to Cameroon in 1991. There, he soon realized that the country was in deep recession, at which point he decided to earn a $\mathrm{PhD}$ in Berlin. He eventually returned to Cameroon on May 1, 2002, and secured a position as lecturer at the University of Buea. The interview took place on October 2, 2008, at his office in Buea.

${ }^{12} \mathrm{Dr}$. G. earned her $\mathrm{PhD}$ in inorganic chemistry at the University of Leipzig and returned on February 1, 2005, to Cameroon. Upon return she secured her position as lecturer at the University of Buea. The interview took place in her office in Buea on October 2, 2008.
} 
Cameroon we will inform the other members of the faculty so that we can make it for the interview". And then I went back and then he called me again and said the interview was set on one day .... I did the interview and then two days after, I left waiting for the flight. (Cameroon interview \#04, 2008)

The quote suggests that Dr. G. did not have a personal contact who gave her information about a vacancy and that she simply applied. But this was only partly true. She mentioned the head of department, Professor A. who invited her for the appointment and was very flexible regarding her situation. Professor A., I found out during my research, was a returnee himself. He thus knew of the struggles of returning graduates. He was known to be very helpful to returning graduates searching for jobs. Hence, in this case again, it was indirectly a contact person that helped Dr. G. to find a vacancy and obtain a job.

Summing up the experiences recounted above, it seems to be difficult to identify the employment demand at universities in both countries. Returnees in Ghana as well as in Cameroon reported that they received valid information about vacancies through their personal contacts rather than through the official advertisement channels of the universities. Luckily, these returning graduates seem to have had wellembedded personal contacts and were eventually able to locate positions as lecturers. However, this job search period upon return creates frictional unemployment, which causes problems for the returning graduates for two reasons. It delays earning an income and it also creates a devaluation of the degrees they acquired in Germany. The longer they have to wait to apply what they learned abroad, the more outdated their knowledge will become.

\section{Overcoming Bureaucratic Hurdles}

The image of being a lecturer at a public university used to be that of having a secure position for lifetime. However, the position as lecturer at a university no longer offers this security. The interviewed returning graduates reported that even if they had identified a position, successfully mastered the job interview, and finally even received a job offer, they often still had to persevere to finally get the employment contract. Then, they mostly only received a fixed-term contract of as assistant lecturers instead of as full-time lecturers. Many of their statements reveal that the process of getting a full-time contract is lengthy and full of bureaucratic hurdles.

Many returnees are surprised by the fact that it takes so long to simply receive their appointment letter once they do have a contract. Those who take a sabbatical for studying abroad on unpaid study leave may assume that they will easily reenter their fixed appointment upon return and immediately receive their salary again. ${ }^{13}$ This is

\footnotetext{
${ }^{13}$ For further information, see SOFRECO (2015, p. 64).
} 
often not the case, as Dr. V. ${ }^{14}$ from Ghana (case \#12) remembered. She had to be very patient until she could work as a lecturer again:

When I was leaving I told them I would come back. So when I finished I wrote to them that I had finished and would like to come back. They [the university officials] also gave me the assurance that they were waiting for me. I started [the process] very early before I finished my defense. They said when the certificate is ready I could apply. So when it was ready, I applied. They also played some game on me. They could not transport me back from Germany, so they refused to give me the appointment letter. That is the university condition ... so they did not want to give me my appointment letter. So although they assured me they did not give me the appointment letter. So fortunately CIM [reintegration subsidy scheme] bought my ticket. When I came [back] the first week, I went to tell them that I am back. So I got my appointment letter and contract. I was also trying other places like Kumasi. But one of my professors didn't want me to leave. He wanted me to stay here .... He was one of my lecturers. He is now at the head of Central University. So it was not that much of a problem, not that difficult. But it is just because of the way they do things. And you have to have patience. (Ghana interview \#12, 2008)

Even though Dr. V. stated that for her the situation was "not that much of a problem, not that difficult," the bureaucratic hurdles severely delayed her starting work. If she had not been able to get external funding for her return flight from one of the reintegration subsidies and if her professor had not insisted on keeping her as a lecturer, she probably would have experienced a much more difficult transition upon her return. Although this scenario is speculative, it should be kept in mind.

Bureaucracy can create tremendous delays as shown by the case of Dr. Y. ${ }^{15}$ from Ghana (case \#14). It took him half a year to receive a contract and payment at a public university in Ghana and another two years to successfully conclude his probation period and became a permanent staff member:

Six months after arrival, that was when I formally got employed with university of Ghana. But before then you had to go through some processes: getting to the department, fundraising yourself, going to an interview giving a presentation [pause]. I went through all that and after six month I got a job as a lecturer here in this department. And once you are employed as a lecturer you are on probation for two years. They want to see whether after those two years your output is good before they recommend you that "yes," now you can stay on full [emphasizes]. So I am three years old here now. So from 2004 to now, three years. So I have gone through my probation period and now I am a full lecturer at the department and it has been a big challenge [emphasizes] because of the huge pressure. (Ghana interview \#14, 2008)

\footnotetext{
${ }^{14} \mathrm{Dr}$. V. earned her doctorate in natural sciences at the University of Bremen. Her return to Ghana was on September 9, 2005. She returned to her employment in the University of Cape Coast, Department of Organic Chemistry as a lecturer. The interview took place at her workplace in Cape Coast, on July 7, 2008.

${ }^{15}$ Dr. Y. earned his doctorate in water management at the Center for Development Studies in Bonn and returned in August 12004 . After a cumbersome bureaucratic act he eventually got a job as a lecturer in agricultural economics at the University of Ghana. The interview was at his office in Accra on July 9, 2008.
} 
What Dr. Y. clearly points out in this section corresponds to Dr. V's experience: That securing a university position takes time, during which returnees lack income. They have to develop a strategy like Dr. Y. for "fundraising yourself."

So when I came down to Ghana of course there was no job .... There was no job but I was quite prepared, knowing the way our system is .... So when I came down in August I knew there wouldn't be an immediate job for me but fortunately I had some contacts around. So I was able to survive by getting some small jobs to do even with the Ministry of Agriculture and other consultancies ... I was actually surviving making some money by using my expertise that I had gathered and especially the $\mathrm{PhD}$ it is good for them. So they made use of my talents and I made some money. So that was keeping me going. That was the way when I arrived and six months after arrival that was when I formally got employed with university of Ghana but before then you had to go through some processes. (Ghana interview \#14, 2008)

Unlike the returnees mentioned previously, Dr. Y. seemed very aware of the fact that he would not get a job appointment immediately after his return and therefore sought consultant jobs on a project basis. He was able to earn money and even supplement his $\mathrm{CV}$ with working experience at the same time.

Whereas Dr. Y. in Ghana was proactive, Dr. L. in Cameroon (case \#05) was not looking ahead as much and thus became the victim of a poorly run university administration. It took him one year to understand the bureaucratic process, which was very personalized:

I came back but it was not so easy, I mean the concept was clear that I will come and teach here but it was not easy because of one or two things. I mean so when I came, so I started teaching as part time .... So I was not satisfied because I cannot leave Germany to come and teach here as part time .... So it was like a self revolution, a rebellion when I went there and met the vice rector in his office in charge of teaching. So he assured me that it was a mistake in terms of the budget. So I was recruited. It was a mistake. It was really a mistake and I had to be recruited immediately. (Cameroon interview \#05, 2008)

The difference between the previously presented cases is obvious. The Ghanaian interviewees found bureaucratic systems that were more transparent-ones they were able to master by planning ahead - than the ones encountered by their Cameroonian counterparts.

These graduates' experiences show that the transitional phase does not end with identifying a vacant position and filling it. Bureaucracy, more precisely the bureaucratic formalities regulating the contract procedure and the promotion path within the university, often significantly delay the process of earning an income for the returning graduates. In consequence, returning graduates must be patient, have financial resources to bridge this interim phase, and, last but not least, the confidence to stay and continue their job search. Those who return willing to start their careers in academia have to believe that they will eventually be able to secure and maintain their positions as full-time lecturers at universities in their native countries. 


\title{
Obtaining and Maintaining a Position
}

Not all returning graduates are convinced that the university is going to be their permanent, full-time employer. This is apparent in the following statement by an interviewee from Ghana, Mrs. N.-C. (case \#23) ${ }^{16}$. She found out about a vacant position at her former university in Ghana-admittedly, thanks to the support from her former professor. Despite this personal contact, she, too, had to be patient while waiting to become a permanent member of staff. This, she said, made her very uncertain and convinced her to develop an alternative income generating activity:

\begin{abstract}
I have just been employed - that was during the last season. I need to get confirmation. Normally when you are employed it is just probation. Two years and after the two years you will be confirmed. And even when you are confirmed your appointment will be on contract basis. Four year contract until you attain the position of associate professor that your appointment will be automatically extended until you reach retirement. So it is not so secure the position and that is what has kept the idea of going to the farming on hold because I believe we could have started on a smaller scale then see it grows. But for my job I have to consolidate it for now. I have to sit down and be writing because that is what will get me going. (Ghana interview \#23, 2009)
\end{abstract}

Dr. N.-C. explained that she had a plan B, in case her initial plan of becoming a university professor failed, which was going into farming as she frankly admitted. At the same time, however, she clearly knew what she had to do for her career at the university, which was writing and publishing texts, and she believed that she could succeed in the field of academia through hard work. Today, she is a full-time associate professor, having obtained her $\mathrm{PhD}$ in the interim, without which her position would have been out of reach.

Job insecurity seemed to be more severe in Cameroon according to the professional trajectories of the interviewees at Cameroonian universities. One of the greatest differences observed between the cases from Ghana and those from Cameroon was that most Cameroonian lecturers were teaching part-time simultaneously at several universities to earn a living. This, of course, is an indication of the high degree of employment insecurity in higher education sector.

A good example of this is the career path of Dr. N. ${ }^{17}$ (Cameroon case \#07). Despite her qualification from Germany she still only was a part time lecturer in physics at three different Cameroonian universities:

I wish I was posted here [University of Yaoundé I] completely, because now in my field at the University of Yaoundé I they are going to open the program for medical physics and I have the medical physicist certificate. And there it would be good for me to be at the

\footnotetext{
${ }^{16}$ Mrs. N.-C. earned her MBA in small and medium-sized enterprise development at the University of Leipzig, returned to Ghana on August 13, 2007, and became a lecturer in management studies at the University of Cape Coast. I interviewed her at a restaurant in Cape Coast on September 4, 2009. The contact continued on a more private level via email and phone.

${ }^{17}$ Dr. N. earned her doctorate in Berlin in the field of medical physics. She returned in September 1999, and at the time of the interview, almost ten years later in 2008, was still not employed fulltime. We conducted the interview in a university room at Yaoundé I on October 4, 2008.
} 
University of Yaounde I and not at the University of Dschang .... I would teach people up to the master's level directly in my field. Currently, I teach only second year in Dschang and third year and I'm only in my field in Douala where I teach the master and doctorate students. So if Yaoundé selects me, I will be more in medical physics and will be available for the medical school of Yaoundé I .... Myself, I would agree. If it works that I am a lecturer, the assignment will be done quickly. But it's something that will happen in one year maybe. $(\text { Cameroon interview \#07, 2008) })^{18}$

It is not too much to assume that there was not much competition in her unique field of medical physics and it is thus surprising that Dr. N. still did not have a full-time position at her favorite university, despite her doctorate and additional working experience. Perhaps it was an individual case, but it seems to have been a structural problem instead, because the next case shows a similar pattern. It is again that of Dr. L. (Cameroon case \#05). He, like Dr. N., was teaching at universities in three different cities at the same time-in Buea, Douala, and Yaoundé:

I also teach at Yaoundé I university since 2004, 2005 and I am teaching also in Douala, where you have an engineering school which is a branch of a university in Central Africa, a branch .... It is French, a corporation. So the program is a typical French program for French Cameroonians and they train engineers, I mean mechanical engineers. But there I am not teaching geology. There I am teaching but what we call quality management. That is quality security and quality safety. (Cameroon interview \#05, 2008)

What is surprisingly similar to the previous case from Cameroon is that Dr. L. was only teaching his main subject in one of his three lecturer positions. Of course this could have indicated Dr. L's broad expertise in other fields, but instead it revealed the low demand for his expertise (geological mining) at local universities.

Another, quite outstanding example from Cameroon is that of Dr. H. (case \#02), ${ }^{19}$ a returnee $\mathrm{PhD}$ graduate. It shows that some returning academics will even go as far as to found their own institution of higher education: a polytechnic institute. He and his wife returned in 2001, after having lived and studied in Leipzig for 14 years. He recalls that his plan to establish such an institution came up when he realized he would not be able to find adequate work in his field of applied physics because of the lack of equipment and funding at the local universities:

The plan for the creation of his institute was fundamentally motivated by the fact that I chose to do the experimental physics ... when I decided on that topic for my $\mathrm{PhD}$ thesis my comrades said I would not be prepared if I wanted to return some day, because those from the fundamental mathematical and physical sciences who want to work in their countries as lecturers realize that they do not have a laboratory to work in because we have no equipment, but we have to be able to carry out experiments to explain applied physics .... I submitted my application dossier and checked for open positions at universities in .... I even sent my application to the teaching ministry, but got no reply ... and I then realized that I would have

\footnotetext{
${ }^{18}$ This interview quote has been translated from French to English by the author of this paper.

${ }^{19}$ Together with his wife, Dr. H. studied physics and geography, after which he pursued his $\mathrm{PhD}$ at the University of Leipzig. They both returned on August 27, 2001, to Cameroon and started their private educational institute. The interview took place on October 2, 2008, at their institute's office in Douala.
} 
to build a working laboratory space that met my needs ... that was one of my motivations.

(Cameroon interview \#02/03, 2008) $)^{20}$

Of course, the example of Dr. H. is not a common one, because few returning graduates have enough financial capital for such a large scale investment. It also needs to be mentioned that it took Dr. $\mathrm{H}$ seven years to redeem his investment in the private institution. But despite the fact that it was a difficult path he chosemaintaining his career in academia by founding an educational institute-it is a very good example of how a long-term investment can ultimately convince returnees to settle permanently in their home country.

Finally, the cases from Ghana and Cameroon discussed in this section reveal that returning academics from both countries face difficulties retaining their employment in academia. However, the cases from Cameroon show that the level of insecurity is higher than in Ghana.

\section{Contribution to Development}

In this final section I go beyond the question of how to find and maintain employment and discuss whether educational migrants achieve structural development effects through their return migration as professionals. Here, the notion of development is one of sustainable development, which includes social, political, environmental, and economic aspects. Analysis of data on the impact of returning graduates on development processes in higher education suggests that an impact on development, especially concerning the economic aspects, was possible. Most returning graduates improved their individual lives and that of their close family members through their limited financial resources. Nearly all returned graduates of this study talked about their presents and gifts, mainly consumer goods and electronic devices, which they brought from abroad for their families and kin. However, this support on an individual level can, of course, only contribute to punctual development. But the lecturers took on the mission of stimulating development within a broader context. This was achieved, interestingly, in the field of natural resource management-and surprisingly was more relevant in the interviews with Ghanaian lecturers.

The notion that Ghanaian lecturers have more impact on development processes could have to do with the fact that many Ghanaians from the sample studied in the field of renewable resources and resource management, which is developmentally oriented per se. That Cameroonian graduates have the same potential for developmental change was made evident by the case of Mr. I. from Cameroon (case \#11) ${ }^{21}$.

\footnotetext{
${ }^{20}$ This interview quote has been translated from French to English by the author of this paper.

${ }^{21}$ After studying environmental resource management at Brandenburgische Technische Universität in Cottbus, Germany, Mr. I. returned on November 1, 2007, to Cameroon. After a job search lasting five months he found employment as an environmental manager at a local NGO in Yaoundé. We met for the interview at his workplace on October 9, 2008.
} 
He was a graduate of an English language master's degree program in natural resource management in Germany. He pointed out that he went to study in Germany because Cameroonian universities lacked expertise in the field of natural resource management:

Cameroon needs many environmental experts. There are no experts. So I said, "Oh, so if there are no experts, if I can study this thing and come back at least I will be an expert". That's when the idea started. And this is [what I said] when they asked me at the German embassy [why I wanted] to go and study. That's when the motivation actually started. And that's when I saw that it's actually true. There is no college; there is no university in Cameroon training people on environmental stuff. (Cameroon interview \#11, 2008)

Mr. I. saw an increasing need for environmental experts in Cameroon arising because of the country's rich natural resources. They represent the country's primary export commodity, but Mr. L. thought that Cameroon lacked the necessary accountability to exploit these resources responsibly:

Our problem in Cameroon is resource management and accountability. If our president is struggling to install accountability, we need people to start teaching resource management. How can we use [our resources]? I think if we will do this, I think Americans will come to Cameroon to work. Yes! Because we may not know how to go about it harnessing diamonds. Diamonds have been discovered in Cameroon, ha? There is bauxite, there is iron that has been discovered and iron ore another, another there is enough gas, natural gas that has been discovered and other, oil, eh, rubber has been discovered in Kumba, still going to be tapped. What will we need to be doing in Europe? Making beds or washing toilets? In fact, it is so upsetting to see a $\mathrm{PhD}$ student cleaning toilets and we are singing, "Hallelujah!" over it. Singing songs over toilets! (Cameroon interview \#11, 2008)

Mr. I. suggested in this quote that there was a need to "start teaching resource management" in Cameroon in order to "install accountability" and to make the local population capable of managing resource exploitation themselves. This, he claimed, would be a countermeasure against the increasing emigration of economic migrants who, in his view, could not access decent employment abroad and often end up in menial jobs. However, despite his expertise in this important field he only held a part-time lecturer position and generated his main income as an employee in a NGO.

Having said that sustainable development also includes a political dimension, it would now be interesting to take a closer look at the returnee graduates' impact in terms of their implementing structural changes. An example is the case of Mr. U. (Ghana case \#10) ${ }^{22}$. Like Mr. I. from Cameroon he only holds a master's degree. But in contrast to Mr. I., he was able to obtain a higher position in the very beginning:

Yeah the qualification I got from Stuttgart, of course it has been very helpful because to lecture in a tertiary institution, the minimum is a master's level and if you have a B. Sc. [bachelor of science] in a polytechnic you can be an instructor but your conditions of service is not good. Getting the master's degree had positioned me in a better place. In fact, there

\footnotetext{
${ }^{22} \mathrm{Mr}$. U. studied water resources engineering and management in Germany and returned on September 27, 2005, and became head of department at the polytechnic in the Volta Region at Ho. The interview took place three years later on July 4, 2008, in Ho.
} 
were other people, who had been in the department before I came. But because they didn't have their master's even though they had a lot of experience in terms of "on the job,", they are now at the background and I just came and I was made the head of department, it was a new, a new thing to me [smiles] .... It is because of the qualification, yes. (Ghana interview $\# 10,2008)$

From Mr. U.'s perspective, his becoming head of department despite his lack of teaching experience was "because of the qualification" in natural resource programs. He indicated that he has even more influence in this position than a lecturer and that he designed the curriculum of the department:

There are some of the courses [in the field of renewable energies] you can't get them here ... there is no institution in Ghana that handles waste management and K-Poly is now trying to work on it. We are developing a curricular .... So for such a course like this we need to train people at the MSc [master of science] level, there is no any fair degree, we don't have technology, we don't have it. MSc we don't have it but each course is run in Germany, water resources ... so for such courses if you don't travel outside then you can't have it and if you don't have it there is no chance, there is no way Ghana will have any education in that line. (Ghana interview \#10, 2008)

Mr. U.'s impact was clearly related to capacity building in the field of environmental resource management because at that time, in 2008, there was "no institution in Ghana that handles waste management." Thanks to the specific knowledge he had gained in Germany, Mr. U. not only improved his individual situation, but also was able to bring significant change to his department by adopting the course curriculum of German universities. He contributed to institution and capacity building.

Ultimately this section about the impact of returning graduates on development processes suggests that Ghanaian returning graduates working currently as lecturers can contribute to environmental education on a larger scale. In comparison, the Cameroonian lecturers were not mentioning such development related activities in the context of their official work and in contrast to their Ghanaian counterparts had greater challenges during their entry into the university. In addition, the need to have a PhD degree was much more obvious in Cameroon. All interviewees among the group of Cameroonian lecturers had their doctorates, whereas it was possible in Ghana find employment with a master's degree, as the example of Mr. U. (case \#10) showed.

\section{Conclusions}

At first glance universities in Sub-Saharan African countries would seem to be ideal employers for returning graduates who studied in the Global North. By disseminating their knowledge from abroad they could contribute to technological catchup, build capacities, and counter the ongoing massive brain drain of highly skilled workforces in the higher education sector. I reveal the contrary. The universities do not fully reap the great potential of returning graduates. My comparison of the labor market entry of graduates in the two Sub-Saharan African countries of Ghana 
and Cameroon shows that the job-finding process in higher education in both countries is lengthy and cumbersome and the matching process rather difficult. What differs is the weighting of the difficulties. The quotes from the interviews (which of course reflect the situation eight years ago) lead to the assumption that recruitment at Cameroonian universities at the time was even more intransparent and insecure than at those in Ghana. In addition the development impact of lecturers seemed to be clearer in the case of Ghanaian academics. Returned graduates in Ghana who worked in the higher education reported how they delivered community services, and many had a particular impact in the field of renewable energies. Ghana's comparably more transparent and open higher education system made it possible for Ghanaian return migrants to make use of their educational expertise in the field of natural resource management. Their educational migration empowered them to foster development processes in their home country of Ghana. In contrast, the system in Cameroon seemed to give returnee graduates more difficulties finding a vacant position at a university, let alone securing it, which even led some graduates to create their own job opportunities by establishing an educational institution (see the case of Dr. and Mrs. H.; Cameroon case \#02). Hence, my interpretation of the empirical material leads me to suggest that Ghanaian universities used the potential of returning academics more effectively than their Cameroonian counterparts.

Does this in consequence mean that career opportunities in academia are too limited for returnee graduates and thus that graduates should not consider returning? This, despite all the obstacles shown in this chapter, is not the case. The solution to overcoming these obstacles lies in the graduates' resources, which they should acquire prior to their return. In order to prepare for their home country's professional reality they first need to build professional academic networks to help in the search for a vacant position. Second, returnees should have secure intermediary financial funding at their disposal because the job search phase may be long. And third—and probably most importantly, they need to acquire an educational profile that matches the country's specific needs. These findings also suggest that preparation schemes, such as reintegration seminars offered by the German government, are still a very important instrument increasing chances that the return of educational migrants will be a brain gain for the source countries as well as for the host country of Germany.

\section{References}

AAU (Association of African Universities). (2015). Member Universities. Retrieved from https:// www.aau.org/subs/membership/

Asong, A. A., \& Awama, S. G. (2014). Le suivi des diplômés de l'université de Buea: 1996-2006 [Tracking graduates of the University of Buea]. In M. S. Kamdem \& E. W. Schamp (Eds.), L'université africaine et sa contribution au développement local: L'exemple du Cameroun (pp. 149-174). Paris: Karthala.

Ausländerzentralregister. (2016). Bevölkerung und Erwerbstätigkeit: Ausländische Bevölkerung 2015. Ergebnisse des Ausländerzentralregisters [Population and employment: Foreign 
population 2015. Results of the Central Register of Foreigners]. Wiesbaden: German Federal Statistical Office.

Bloom, D., Canning, D., \& Chan, K. (2006). Higher education and economic development in Africa (No. 102). Retrieved from http://ent.arp.harvard.edu/AfricaHigherEducation/Reports/ BloomAndCanning.pdf

Boger, J. (2013). Ghanaian 'green-degree' graduates returning from Germany and their impact on environmental development in Ghana. Challenging Notions of Development and Change from Everyday Life in Africa, 4, 86-122. Retrieved from https://epub.uni-bayreuth.de/113/1/ BIGSASworks_4_05oct2013.pdf

Boger, J. (2014). The job hunt: Return migration and labour market entries of Cameroonian and Ghanaian graduates from German universities. Wiesbaden: World University Service.

Cassarino, J.-P. (2004). Theorising return migration: The conceptual approach to return migrants revisited. International Journal on Multicultural Societies, 6, 253-279. doi:https://doi.org/10. 1590/S1980-85852013000200003

Chien, C.-L., \& Kot, F. C. (2012). New patterns in student mobility in the southern Africa development. UIS Information Bulletin No. 7. Retrieved from http://unesdoc.unesco.org/ images/0021/002170/217095e.pdf

Cerase, F. P. (1974). Expectations and reality: A case study of return migration from the United States to Southern Italy. International Migration Review, 8, 245-262. doi:https://doi.org/10. $2307 / 3002783$

de Haas, H. (2008). Migration and development: A theoretical perspective. International Migration Institute (IMI Working Papers). Retrieved from http://www.imi.ox.ac.uk/pdfs/wp/wp-09-08.pdf

de Haas, H. (2012). The Migration and Development pendulum: A critical view on research and policy. International Migration, 50(3), 8-25. doi:https://doi.org/10.1111/j.1468-2435.2012.00755.x

Faist, T. (2008). Migrants as transnational development agents: An inquiry into the newest round of the migration-development nexus. Population Space Place, 14, 21-42. 10.1002\%2fpsp.471

German Federal Statistical Office. (2015a). Origin of foreign students, Bildungsauslaender and Bildungsinlaender students in 2015 by continents, regions and countries of origin. Retrieved from http://www.wissenschaftweltoffen.de/daten/1/2/1?lang=en

German Federal Statistical Office. (2015b). The number of Bildungsauslaender students from the 20 most important countries of origin in 2015-development in medium-term from 1999 to 2015. Retrieved from http://www.wissenschaftweltoffen.de/daten/1/2/3?lang=en

Ghanaweb. (2015). Universities in Ghana. Retrieved from http://www.ghanaweb.com/ GhanaHomePage/education/universities.html

Hahn, H.-P., \& Klute, G. (2007). Cultures of migration: African perspectives. Beiträge zur Afrikaforschung: Vol. 32. Berlin: LIT. Retrieved from https://openaccess.leidenuniv.nl/ bitstream/handle/1887/12923/ASC-140170847-131-01.pdf?sequence=2

Krings, M. (2003). Diaspora: Historische Erfahrung oder wissenschaftliches Konzept? Zur Konjunktur eines Begriffs in den Sozialwissenschaften [Historical experience or scientific concept? On a booming concept in the social sciences]. Paideuma, 49, 137-156. Retrieved from http://www.jstor.org/stable/40315515

Kuptsch, C. (2006). Students and talent flow-the case of Europe: From castle to harbour? In C. Kuptsch \& E. F. Pang (Eds.), Competing for global talent (pp. 33-61). Geneva: International Institute for Labour Studies. Retrieved from http://citeseerx.ist.psu.edu/viewdoc/download; jsessionid=30B2EE7ADDA235E6CA8ED89F52374B1A?doi=10.1.1.120.2008\&rep $=$ rep1\& type $=$ pdf

Manuh, T., Asante, R., \& Djangmah, J. (2005). The brain drain in the higher education sector. In T. Manuh (Ed.), At home in the world? International migration and development in contemporary Ghana and West Africa (pp. 250-276). Legon: Sub-Saharan.

Martin, J. (2005). Been-To, Burger, Transmigranten? Zur Bildungsmigration von Ghanaern und ihrer Rückkehr aus der Bundesrepublik Deutschland [Been-To, Burger, Transmigrants. Educational migration and the reintegration of Ghanaians from Germany]. Beiträge zur Afrikaforschung: Vol. 22. Berlin: LIT. 
Mbah, M. (2014). Brain Drain aus Entwicklungsländern? Migrationsmotive- und prozesse Hochqualifizierter am Beispiel von Nigeria. [Brain drain from developing countries? Migration motives and processes of the highly skilled as exemplified by Nigeria]. Karlsruhe: University of Karlsruhe. Retrieved http://digbib.ubka.uni-karlsruhe.de/volltexte/1000042111

Mbah, M. (2017). Formal education as a facilitator of migration and integration: A case study of Nigerian university graduates. In H. Jöns, P. Meusburger, \& M. Heffernan (Eds.), Mobilities of knowledge (pp. 247-268). Knowledge and Space: Vol. 10. Cham: Springer. doi:https://doi.org/ 10.1007/978-3-319-44654-7_13

Ministry of Higher Education. (2014). L'enseignement supérieur au Cameroun: Cartographie 2014 des Institutions [Higher education in Cameroon: 2014 atlas of the institutions]. Retrieved from http://www.minesup.gov.cm/1.1.\%20cartographie\%202014\%20de\%201'enseignement\%20sup $\% 20$ au\%20Cameroun $1 \% 20 \% 20 \% 20 \% 20 \% 20$.pdf

Morris-Lange, S., \& Brands, F. (2015). Zugangstor Hochschule: Internationale Studierende als Fachkräfte von morgen gewinnen [The university as entryway: How to recruit international students as tomorrow's professionals]. Retrieved from http://www.svr-migration.de/wp-con tent/uploads/2015/06/Studie_Zugangstor-Hochschule_SVR-FB_Web.pdf

Mugabushaka, A.-M., Teichler, U., \& Schomburg, H. (2003). Failed or self-hindering prophecies? Employment experiences of African graduates in the 1990s. Journal of Higher Education in Africa, 1(1), 57-77. Retrieved from http://www.jstor.org/stable/24486114

National Accreditation Board. (2015). Public universities Ghana. Retrieved from http://www.nab. gov.gh/public-universities

Neubert, D. (2008). Academic cooperation between Germany and Africa-challenges and some lessons learnt. In E. W. Schamp \& S. Schmid (Eds.), Academic cooperation with Africa: Lessons for partnership in higher education (pp. 93-110). Berlin: LIT.

Nyberg-Sørensen, N., Van Hear, N., \& Engberg-Pedersen, P. (2002). The migration-development nexus: Evidence and policy options. International Migration, 40(5), 3-47. doi:https://doi.org/ 10.1111/1468-2435.00210

Nyonator, F., \& Dovlo, D. (2005). The health of the nation and the brain drain in the health sector. In T. Manuh (Ed.), At home in the world? International migration and development in contemporary Ghana and West Africa (pp. 227-249). Legon: Sub-Saharan.

OECD (Organization for Economic Co-operation and Development). (2014). Education at a Glance 2014: OECD indicators. Paris: OECD. Retrieved from https://www.oecd.org/edu/Edu cation-at-a-Glance-2014.pdf

Owono, J. (2011, October 13). Cameroun: La diaspora s'est abstenue de voter à l'élection présidentielle [Cameroon: Diaspora fails to participate in elections]. Global Voices en Français. Retrieved from http://fr.globalvoicesonline.org/2011/10/13/83633/print/

Portes, A. (2003). Conclusion: Theoretical convergencies and empirical evidence in the study of immigrant transnationalism. International Migration Review, 37, 874-892. doi:https://doi.org/ 10.1111/j.1747-7379.2003.tb00161.x

Quartey, P. (2009). Migration in Ghana: A country profile 2009. Geneva: International Organization for Migration. Retrieved from https://publications.iom.int/system/files/pdf/ghana_profile_ 2009_0.pdf

Sapouma, C. (2011, August 19). Enfin le droit de vote pour les Camerounais de l'étranger [Finally the right to vote for Cameroonians from abroad]. Slate Afrique. Retrieved from http://www. slateafrique.com/print/22427/elections-enfin-le-droit-de-vote-pour-les-ca

Saxenian, A. (2005). From brain drain to brain circulation: Transnational communities and regional upgrading in India and China. Studies in Comparative International Development, 40(2), 35-61. doi:https://doi.org/10.1007/BF02686293

Schamp, E. W., \& Zajontz, Y. (2008). Patterns of international academic communication at African universities: Cameroon, a case study of a bilingual country. In E. W. Schamp \& S. Schmid (Eds.), Academic cooperation with Africa: Lessons for partnership in higher education (pp. 55-76). Berlin: LIT. 
Schamp, E. W. (2014). Université et développement régional en Afrique: Le défi de nouvelles idées et de nouvelles exigences à l'heure de la globalisation [University and regional development in Africa: The challenge of new ideas and demands in the age of globalization]. In M. S. Kamdem \& E. W. Schamp (Eds.), L'université africaine et sa contribution au développement local: L'exemple du Cameroun [The African university and its contribution to local development: The example of Cameroon] (pp. 19-39). Paris: Karthala.

Schmidt-Fink, E. (2009). Erfassung der Rückkehrhilfesysteme in den Bundesländern: Untersuchung im Auftrag der Landeshauptstadt München: Büro für Rückkehrhilfen Projekt Coming Home [Compilation of assisted voluntary return schemes in the federal states: Investigation commissioned by the state capital Munich: Office for the Coming Home project] [Brochure]. Retrieved from http://www.muenchen.info/soz/pub/pdf/303 rueckkehrhilfesysteme.pdf

Skeldon, R. (2005). Globalization, skilled migration and poverty alleviation: Brain Drains in context (Working Paper No. T15). Retrieved from http://www.migrationdrc.org/publications/ working_papers/WP-T15.pdf

SOFRECO. (2015). Study on the contribution of the alumni and diaspora to the Joint Africa-EU Strategy: Final report (Framework Service Contract No EAC/02/2010). Retrieved from http:// ec.europa.eu/education/news/2015/documents/study-sofreco-eu-africa_en.pdf

Teferra, D., \& Altbach, P. G. (2004). African higher education: Challenges for the 21st century. Higher Education, 47, 21-50. doi:https://doi.org/10.1023/B:HIGH.0000009822.49980.30

Thomas, K. J. A. (2008). Return migration in Africa and the relationship between educational attainment and labour market success: Evidence from Uganda. International Migration Review, 42, 652-674. doi:https://doi.org/10.1111/j.1747-7379.2008.00141.x

UIS (UNESCO Institute for Statistics). (2010). Trends in tertiary education: Sub-Saharan Africa (UIS Fact Sheets No. 10). Retrieved from http://unesdoc.unesco.org/images/0019/001926/ 192603e.pdf

UIS (UNESCO Institute for Statistics). (2012). Global Education Digest 2012: Opportunities lost: The impact of grade repetition and early school leaving. Retrieved from http://unesdoc.unesco. org/images/0021/002184/218449e.pdf

UNDP (United Nations Development Program). (2015). Human Development Report 2015: Work for Human Development (Publication No. E.15.III.B.1). Retrieved from http://hdr.undp.org/ sites/default/files/2015_human_development_report_1.pdf

Vertovec, S. (2007). Circular migration: The way forward in global policy? (International Migration Institute Working Papers: No. 4). Retrieved from https://www.imi.ox.ac.uk/publications/ wp-04-07

World Bank (2000). Higher education in developing countries: Peril and promise (Published for the Task Force on Higher Education and Society). Retrieved from http://siteresources. worldbank.org/EDUCATION/Resources/278200-1099079877269/547664-1099079956815/ peril_promise_en.pdf

World Bank (2009). Accelerating catch-up: Tertiary education for growth in Sub-Saharan Africa. (Directions in development: Human development, No. 45275). Retrieved from http://wwwwds. worldbank.org/external/default/WDSContentServer/WDSP/IB/2009/01/27/000333038_ 20090127223030/Rendered/PDF/462750Revised017808213773830Revised.pdf

World Bank (2010). Financing higher education in Africa. (Directions in development: Human development, No. 54441). Retrieved from http://wwwwds.worldbank.org/external/default/ WDSContentServer/WDSP/IB/2010/05/11/000333037_20100511005406/Rendered/PDF/ 544410PUB0EPI01BOX0349416B01PUBLIC1.pdf

World Bank (2011). Migration and remittances factbook 2011 (2nd ed.). Washington DC: The World Bank. 
Zajontz, Y. (2010). Afrikanische Universitäten als Motoren regionaler Entwicklung? Eine Analyse von Wissenskanälen an drei peripheren Universitäten in Kamerun [African universities as motors of regional development? An analysis of knowledge channels at three peripheral universities]. Lehre \& Forschung — Hochschule im Fokus: Vol. 7. Hamburg: Dr. Kovac.

Zips, W. (Ed.) (2003). Afrikanische Diaspora: Out of Africa-Into New Worlds [African Diaspora: Out of Africa-into new worlds]. Afrika und ihre Diaspora, Vol. 1 [Africa and its diaspora], Berlin: LIT.

Zweig, D. (2006). Learning to compete: China's efforts to encourage a "reverse brain drain". In C. Kuptsch \& E. F. Pang (Eds.), Competing for global talent (pp. 187-213). Geneva: International Institute for Labour Studies.

Open Access This chapter is licensed under the terms of the Creative Commons Attribution 4.0 International License (http://creativecommons.org/licenses/by/4.0/), which permits use, sharing, adaptation, distribution and reproduction in any medium or format, as long as you give appropriate credit to the original author(s) and the source, provide a link to the Creative Commons license and indicate if changes were made.

The images or other third party material in this chapter are included in the chapter's Creative Commons license, unless indicated otherwise in a credit line to the material. If material is not included in the chapter's Creative Commons license and your intended use is not permitted by statutory regulation or exceeds the permitted use, you will need to obtain permission directly from the copyright holder. 